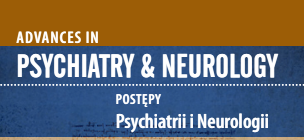

Correspondence to / Adres do korespondencii:

Adam Wichniak

III Klinika Psychiatryczna

Instytut Psychiatrii i Neurologii

ul. Sobieskiego 9

00-957 Warszawa, Polska

e-mail: wichniak@ipin.edu.pl

Submitted / Otrzymano: 25.10.2020

Accepted / Przyjęto do druku: 14.12.2020

\section{SIMPLIFIED INTERVIEW FOR NEGATIVE AND POSITIVE SYMPTOMS (SNAPSI) AND THE PANSS-6 SCALE - POLISH LANGUAGE ADAPTATION AND APPLICATION}

\author{
UPROSZCZONY WYWIAD OBJAWÓW \\ NEGATYWNYCH I POZYTYWNYCH \\ (SNAPSI) I SKALA PANSS-6 - \\ POLSKA ADAPTACJA JĘZYKOWA \\ I ZASTOSOWANIE
}

\author{
Kaja Wojciechowska, Małgorzata Walęcka, Joanna Szmyd, \\ Adam Wichniak
}

$3^{\text {rd }}$ Department of Psychiatry, Institute of Psychiatry and Neurology, Warsaw, Poland

III Klinika Psychiatryczna, Instyłut Psychiatrii i Neurologii w Warszawie, Polska

\begin{abstract}
Purpose: The treatment of schizophrenia requires regular assessment of the patient's mental state. The quantitative assessment of the severity of schizophrenia symptoms is performed using clinical scales, most often the PANSS scale. However, the scale is rarely used in everyday clinical work as the assessment itself is very time-consuming. A Simplified Interview for Negative and Positive Symptoms (SNAPSI) and the PANSS-6 scale have been proposed as practical methods to facilitate the quantitative assessment of the patient's mental state. The aim of the article is to present both of those tools and their adaptation to the Polish language.

Views: The PANSS-6 scale consists of six items taken from the PANSS scale, which assess delusions, hallucinatory behaviour, conceptual disorganization, passivity/apathy, social withdrawal, blunted affect, lack of spontaneity and a fluent conversation. Among the advantages of PANSS-6 are scalability, high correlation with full PANSS assessment results and sensitivity to changes in the patient's mental state during antipsychotic treatment. SNAPSI is a semi-structured interview which enables the assessment of the PANSS-6 scale, the assessment of selected items of the Brief Psychiatric Assessment Scale (BPRS), and the Brief Negative Symptoms Scale (BNSS), as well as the assessment of the overall severity of symptoms with the General Clinical Impression (CGI) scale. It takes between 15 to 25 minutes.

Conclusions: Both tools have been adapted to Polish, in accordance with the recommendations regarding the adaptation of scales and clinical tests to other languages. They are being disseminated publicly through a website and can be used free of charge in medical and non-commercial scientific research.
\end{abstract}

Key words: schizophrenia, mental state assessment, PANSS scale.

\title{
Streszczenie
}

Cel: Leczenie schizofrenii wymaga regularnej oceny stanu psychicznego pacjenta. W badaniach naukowych ilościowa ocena nasilenia objawów schizofrenii dokonywana jest z użyciem skal klinicznych, najczęściej skali PANSS. Skala ta jest jednak rzadko stosowana w codziennej pracy klinicznej z powodu czasochłonności takiej oceny. Uproszczony Wywiad Objawów Negatywnych i Pozytywnych (SNAPSI) oraz skala PANSS-6 są propozycjami metod praktycznych w użyciu, które ułatwiają ilościową ocenę stanu psychicznego pacjenta. Celem artykułu jest przedstawienie obu tych narzędzi oraz opisanie procesu ich adaptacji na język polski.

Poglądy: Skala PANSS-6 składa się z sześciu jednostek wybranych z pełnej wersji skali PANSS, oceniających: urojenia, zachowania omamowe, dezorganizację pojęciową, bierność/apatię, społeczne wycofanie, spłycenie afektu oraz brak spontaniczności i płynności rozmowy. Jej zaletami są skalowalność, wysoka korelacja z wynikami oceny pełną skalą PANSS oraz czułość na zmiany stanu 
psychicznego pacjenta w trakcie leczenia przeciwpsychotycznego. Wynik skali PANSS-6 poniżej 14 pkt wskazuje, że pacjent jest w stanie remisji. Uproszczony Wywiad Objawów Negatywnych i Pozytywnych (SNAPSI) jest wywiadem półustrukturalizowanym. Umożliwia dokonanie oceny skalą PANSS-6, a także oceny wybranych pozycji Krótkiej Skali Oceny Psychiatrycznej (BPRS), Krótkiej Skali Objawów Negatywnych (BNSS) i ogólnego nasilenia objawów Skalą Ogólnego Wrażenia Klinicznego (CGI). Czas jego przeprowadzenia wynosi 15-25 minut.

Wnioski: Oba narzędzia zostały zaadaptowane na język polski za zgodą autorów i zgodnie z zaleceniami odnośnie do adaptacji skal i testów klinicznych na inne języki. Narzędzia te są upowszechnione publicznie poprzez stronę internetową i mogą być bezpłatnie wykorzystywane w działalności leczniczej i niekomercyjnych badaniach naukowych.

Słowa kluczowe: schizofrenia, ocena stanu psychicznego, skala PANSS.

\section{INTRODUCTION}

Schizophrenia is a severe, destructive mental illness that affects various areas of a patient's functioning. The basic form of treatment for schizophrenia is pharmacotherapy, which requires regular assessment of the patient's mental state and monitoring of treatment tolerance [1]. The PANSS scale is one of the most commonly used to measure the severity of illness. It enables assessment on a scale from 1 - no symptom, up to 7 - extremely severe, in 30 symptoms of the illness. The symptoms are divided into 3 groups: positive, negative and general [2]. A total PANSS score lower or close to 60 points means that symptoms are of mild severity whereas a result of around 95 points means moderate severity, and a score of 116 points describes severe symptoms [3]. The PANSS scale's popularity in scientific and clinical studies stems from the fact that it allows for the assessment of many symptoms, including negative symptoms that are often overlooked in routine clinical assessment, despite being the prevailing symptoms of the illness which adversely affect the patient's functioning and quality of life $[4,5]$. Unfortunately, the full implementation of the PANSS scale is time-consuming; it usually takes between 40 to 60 minutes to complete. For this reason, it is not widely used by physicians in everyday clinical practice. In order to increase the PANSS scale's practicality for clinicians, attempts are being made to develop a shorter versions. On the one hand, these should facilitate the reliable and accurate measurement of schizophrenia symptoms, and thus enable more prudent decisions about the patient's treatment plan to be made. On the other hand, they must be practical to use [6]. This means, among other things, that their administration time should not exceed 20 minutes. One of the proposed abbreviated versions of the PANSS scale is the PANSS- 6 scale, assessed on the basis of the Simplified Negative and Positive Symptoms Interview (SNAPSI). The aim of this article is to present both of the aforementioned tools used in the patient's mental state assessment and their adaptation to the Polish language.

\section{WPROWADZENIE}

Schizofrenia jest ciężką chorobą psychiczną wpływającą destrukcyjnie na różne obszary funkcjonowania pacjenta. Podstawową formą jej leczenia jest terapia farmakologiczna, która wymaga regularnej oceny stanu psychicznego pacjenta i monitorowania tolerancji leczenia [1]. Najczęściej używaną skalą do pomiaru nasilenia objawów choroby jest skala PANSS. Umożliwia ona ocenę w skali od 1 - brak objawu, do 7 - nasilenie skrajnie ciężkie; obejmuje aż 30 objawów choroby podzielonych na 3 grupy: objawy pozytywne, negatywne i ogólne [2]. Całkowity wynik skali PANSS niższy lub zbliżony do 60 pkt oznacza łagodne nasilenie choroby, w okolicach 95 pkt - umiarkowane nasilenie objawów, a w granicach 116 pkt - ciężkie nasilenie choroby [3]. Popularność skali PANSS $\mathrm{w}$ badaniach naukowych i klinicznych wykonywanych $\mathrm{z}$ udziałem chorych na schizofrenię wynika $\mathrm{z}$ tego, że umożliwia ona ocenę wielu objawów choroby, które są często niewystarczająco dostrzegane podczas rutynowej oceny klinicznej, np. objawów negatywnych, nierzadko przeważających $\mathrm{w}$ obrazie choroby $\mathrm{i}$ istotnie negatywnie wpływających na funkcjonowanie i jakość życia pacjenta $[4,5]$. Niestety wykonanie skali PANSS jest czasochłonne, wymaga poświęcenia 40-60 minut. $\mathrm{Z}$ tego powodu skala ta nie jest powszechnie stosowana przez lekarzy w codziennej praktyce klinicznej. W celu zwiększenia praktyczności użycia skali PANSS przez lekarzy klinicystów podejmowane są próby opracowania jej krótszych wersji. Powinny one z jednej strony ułatwiać rzetelny i trafny pomiar objawów schizofrenii, a przez to umożliwiać podejmowanie bardziej rozważnych decyzji co do sposobu leczenia pacjenta, z drugiej - muszą być praktyczne w użyciu [6]. Oznacza to m.in., że ich czas wykonania nie powinien przekraczać 20 minut. Jedną z propozycji skróconych wersji skali PANSS jest skala PANSS-6, oceniana na podstawie Uproszczonego Wywiadu Objawów Negatywnych i Pozytywnych (Simplified Negative and Positive Symptoms Interview - SNAPSI). Celem artykułu jest przedstawienie obu tych narzędzi oceny stanu psychicznego pacjenta oraz ich adaptacji na język polski. 


\section{SNAPSI AND PANSS-6 - MAIN ASSUMPTIONS AND AREAS OF ASSESSMENT}

The PANSS- 6 scale was proposed in 2016 by a clinical team led by Dr. Søren D. Østergaard [7]. On the basis of data from two clinical studies involving nearly 500 and 200 patients with schizophrenia respectively, they assessed the psychometric properties of the full and abbreviated versions of the PANSS scale - PANSS-14 and PANSS-8. The analysis of the scales' usefulness was performed by measuring the efficacy of sertindole and haloperidol treatment in comparison to placebo [7]. These assessments showed that none of the PANSS scale versions met the psychometric requirements assumed by the authors. The most important of them was the expectation that the total score must be scalable, meaning that each scale item adds new information by assessing distinct symptom of the illness. As a result of this analysis the authors proposed a version of the PANSS scale consisting of only 6 items and assessing the following symptoms, each of which indicates a greater severity of the illness: P1 - Delusions, P3 - Hallucinationatory behaviours, P2 Conceptual disorganization, N4 - Passivity/Apathy, Social withdrawal, N1 - Flattening of affect, N6 - Lack of spontaneity and fluency of conversation [7]. The same research team also created the SNAPSI. It can be used to perform the PANSS- 6 assessment as well as additionally selected items from several commonly used psychiatric assessment scales [8], e.g. the Brief Psychiatric Rating Scale (BPRS) [9] and the Brief Negative Symptoms Scale (BNSS) [10, 11]. Moreover, The SNAPSI interview allows for the overall assessment of the severity of symptoms by using the General Clinical Impression Scale (CGI) [12]. The SNAPSI interview is intended to serve as a semi-structured interview. It consists of two parts. The first part involves a conversation with the patient and contains both open and closed questions regarding hallucinatory behaviour, delusions, blunted affect, social withdrawal and conceptual disorganization. The second part concerns the interview conducted with healthcare personnel, family members, carers or friends of the patient in order to more accurately assess the severity of such symptoms as delusions, hallucinations and social withdrawal $[8,13]$.

The semi-structured nature of SNAPSI is its undoubted advantage, because it allows the assessor to adjust the questions and time intervals to every patient's individual needs. Additionally, SNAPSI allows for a rudimentary assessment of cognitive functioning in the areas of executive functions, planning and organization. One of the open questions which helps in that requires the patient to describe what steps they would take when going to a doctor's appointment. They are asked to pro-

\section{SNAPSI I PANSS-6 - ZAŁOŻENIA I OBSZARY OCENY}

Skala PANSS-6 została zaproponowana w 2016 r. przez zespół kliniczny pod kierownictwem dr. Sørena D. Østergaarda [7]. Na podstawie danych z dwóch badań klinicznych z udziałem, odpowiednio, blisko 500 i 200 chorych na schizofrenię oceniono właściwości psychometryczne pełnej i skróconych wersji skali PANSS - PANSS-14 i PANSS-8, oraz wykonano analizę użyteczności tych skal $\mathrm{w}$ pomiarze skuteczności leczenia sertindolem i haloperidolem w porównaniu z placebo [7]. Żadna z ocenianych wersji skali PANSS nie spełniła założonych przez autorów wymagań psychometrycznych. Najważniejszym z nich było oczekiwanie, że całkowity wynik oceny musi być skalowalny, czyli że każda jednostka skali dodaje nowe informacje, oceniając odrębne objawy, których występowanie świadczy o narastającej ciężkości choroby. W wyniku przeprowadzonej oceny i analizy autorzy zaproponowali wersję skali PANSS składającą się tylko z 6 jednostek oceniających następujące objawy: P1 - urojenia, P3 - zachowania omamowe, P2 - dezorganizacja pojęciowa, N4 - bierność/apatia, społeczne wycofanie, N1 - spłycenie afektu, N6 - brak spontaniczności i płynności rozmowy. Każdy kolejny objaw świadczy o większym nasileniu choroby [7]. Ten sam zespół naukowców opracował również Uproszczony Wywiad Objawów Negatywnych i Pozytywnych (SNAPSI), który może być stosowany w celu wykonania oceny skalą PANSS-6, ale też wybranych elementów z kilku powszechnie stosowanych skal oceny psychiatrycznej [8], np. wybranych pozycji z Krótkiej Skali Oceny Psychiatrycznej (BPRS) [9] i Krótkiej Skali Objawów Negatywnych (BNSS) $[10,11]$. Wywiad SNAPSI umożliwia także ocenę ogólnego stopnia nasilenia objawów, np. z użyciem Skali Ogólnego Wrażenia Klinicznego (CGI) [12]. Z założenia wywiad SNAPSI ma służyć jako wywiad półustrukturalizowany. Składa się z dwóch części. Pierwsza dotyczy rozmowy z pacjentem i zawiera pytania zamknięte i otwarte dotyczące zachowań omamowych, urojeń, spłyconego afektu, wycofania społecznego oraz dezorganizacji pojęciowej. Druga część dotyczy rozmowy z personelem opieki zdrowotnej, rodziną, opiekunami lub przyjaciółmi pacjenta - w celu bardziej dokładnej oceny nasilenia takich objawów, jak urojenia, zachowania omamowe, wycofanie społeczne $[8,13]$.

Półustrukturalizowany charakter SNAPSI jest jego niewątpliwą zaletą, ponieważ pozwala osobie wykonującej ocenę na dostosowanie pytań do wybranego przedziału czasowego i do potrzeb oceny danego pacjenta. Narzędzie pozwala również na orientacyjną ocenę funkcjonowania poznawczego w zakresie funkcji wykonawczych, planowania i organizacji. Jedno z uwzględnionych pytań ma charakter otwarty i polega na ocenie, jak np. pacjent planuje wizytę u lekarza. W tym celu jest on proszony, aby podał wszystkie czynności (minimum 
vide the necessary steps (at least 6) that must be carried out to complete the task. What is more, the assessment of severity regarding disorganised behaviour and abnormal thinking symptoms is possible due to the open-ended nature of some SNAPSI questions. Those symptoms are often insufficiently investigated if the doctor uses only closed-ended questions during the examination of the patient's mental state.

\section{THE ADAPTATION OF SNAPSI AND PANSS-6 TO THE POLISH LANGUAGE}

The process of translation and adaptation of the tool to a given language and to the conditions of a given culture includes 8 key stages: (1) selection of the tool to translate and adapt, followed by obtaining the consent to perform a translation from the copyright owner, (2) selection of qualified translators, (3) selection of qualified experts in the tool's field, who will assess the quality of the translation made, (4) selection of the translation method, e.g. two independent translations with comparison of the translations by a third party, (5) use of an appropriate adaptation method, (6) back translation and comparison with the tool's original version, (7) assessment of the translation's practicality, (8) if necessary, assessing the psychometric properties of the adapted tool [14].

The translation and adaptation of the new tool may require changing the content and wording of certain questions due to the social context. For this reason, in the process of adapting a given language version the goal is to faithfully convey the sense of a given phrase. Therefore, adaptation is not always about providing a literal translation. Furthermore, in the case of diagnostic tools the correct adaptation also includes conducting studies that lead to the creation of population norms [15].

The translation and adaptation of the PANNS-6 scale and the SNAPSI to the Polish conditions was started in 2017. The interview's adaptation was created following the authors recommendations and only after obtaining the consent of the copyright owners (Aarhus University, MedAvante-ProPhase LLC, The Feinstein Institute for Medical Research). Firstly, the authors accepted the competence of the persons performing the adaptation. Secondly, two independent Polish-to-English translations of the interview were performed by two psychologists (KW, JSZ) who work with patients suffering from schizophrenia spectrum disorders on a daily basis. In the next step, the specialist psychiatrist (AW) pointed out clinically significant discrepancies in both translations. Later, everyone involved in the translation discussed and finally agreed on a coherent version created from both translations. In the next stage, another psychologist (MW),
6 etapów), które należy wykonać, aby taką wizytę zrealizować. Otwarty charakter części pytań zawartych w SNAPSI umożliwia także ocenę nasilenia dezorganizacji zachowania i zaburzeń toku myślenia pacjenta. Objawy te często nie są wystarczająco dostrzegane, jeśli lekarz w badaniu stanu psychicznego pacjenta używa tylko pytań zamkniętych.

\section{ADAPTACJA SNAPSI I PANSS-6 NA JĘZYK POLSKI}

Proces prawidłowego wykonania tłumaczenia i adaptacji narzędzia na dany język i do warunków danej kultury obejmuje 8 kluczowych etapów: 1) wybór narzędzia do tłumaczenia i adaptacji oraz uzyskanie zgody właściciela praw autorskich na wykonanie tłumaczenia, 2) wybór wykwalifikowanych tłumaczy, 3) wybór wykwalifikowanych ekspertów w obszarze stosowania narzędzia, którzy ocenią jakość przygotowanego tłumaczenia, 4) wybór metody tłumaczenia, np. dwa niezależne tłumaczenia i porównanie tłumaczeń przez osobę trzecią, 5) zastosowanie odpowiedniej metody adaptacji, 6) wykonanie tłumaczenia wstecznego i porównanie $\mathrm{z}$ oryginalną wersją narzędzia, 7) dokonanie oceny praktyczności użycia przygotowanego tłumaczenia, 8) jeśli to konieczne, wykonanie odpowiednich ocen właściwości psychometrycznych zaadaptowanego narzędzia [14].

Ze względu na kontekst społeczny tłumaczenie i adaptacja nowego narzędzia mogą być związane $z$ koniecznością wprowadzenia zmian $\mathrm{w}$ treści pewnych pytań i sformułowań. $Z$ tego powodu w procesie ustalania danej wersji językowej ważne jest jak najwierniejsze oddanie sensu danego sformułowania, a nie zawsze dokładne tłumaczenie. $\mathrm{W}$ przypadku narzędzi diagnostycznych poprawnie przeprowadzona adaptacja danego narzędzia na określony język na późniejszym etapie zawiera też przeprowadzenie badań i stworzenie norm dla danego kraju [15].

Tłumaczenie i adaptacja do warunków polskich skali PANNS-6 oraz SNAPSI rozpoczęły się w 2017 r. Pierwszym krokiem było uzyskanie zgody właścicieli praw autorskich (Aarhus University, MedAvante-ProPhase LLC, The Feinstein Institute for Medical Research) i zaakceptowanie przez nich kompetencji zawodowych osób wykonujących adaptację. Proces adaptacji przebiegał zgodnie z zaleceniami autorów. Polegał na przygotowaniu dwóch niezależnych tłumaczeń wywiadu na język polski przez psychologów (KW, JSZ), którzy na co dzień pracują z pacjentami chorymi na zaburzenia $\mathrm{z}$ kręgu schizofrenii. Następnie lekarz specjalista psychiatra (AW) wskazał na istotne klinicznie rozbieżności w obu tłumaczeniach. Powyższe osoby w toku dyskusji i głosowaniu uzgodniły i stworzyły spójną wersję z obu tłumaczeń. Na następnym etapie psycholog biegle znający język angielski (MW) dokonał tłumaczenia zwrotnego wywiadu, które 
fluent in English, made a back translation of the interview (Polish to English). It was then sent to the tool's authors, for them to check the translation's compliance with the original version. The translation underwent repeated iterations that took into account the authors feedback until the final version was obtained. It was later graphically edited and subjected to practical assessment by five psychiatrists who examined their patients' mental state using the SNAPSI interview. The feedback from practical assessment called for further minor adjustments in the adaptation. After the tool's authors greenlit the revised version, the Polish adaptation of the SNAPSI interview became publicly available in 2019 via the website http://www.medavante-prophase.com/snapsi/ and can be used free of charge in medical work and in non-commercial scientific research.

\section{DISCUSSION}

SNAPSI and the PANSS-6 scale were developed to enable a quantitative assessment of the severity of schizophrenia symptoms not only under the conditions of scientific research, but also in everyday clinical work [8]. It takes around 15-25 minutes to conduct the SNAPSI interview and perform the PANSS assessment. Six core symptoms of schizophrenia are being assessed: three positive symptoms (delusions, hallucinatory behaviours and conceptual disorganization) and three negative symptoms (passivity/apathy and social withdrawal, blunt affect, lack of spontaneity and fluency of conversation). The PANSS-6 scale meets the scalability criteria. Each item of the scale assesses a separate symptom and provides new information about the patient's mental state. Therefore, the results for each symptom can be added, creating the total scale sum which may be treated as a quantitative measurement of the severity of the illness. This means that the severity of the symptoms is proportional to the PANSS-6 score [7]. The scalability condition is not fulfilled for the full version of the PANSS scale, nor is for its earlier proposed shorter versions (PANSS-14 and PANSS-8). This is a serious limitation of the PANSS scale, in addition to the long time needed to complete it (40-60 minutes). Studies have shown that the PANSS- 6 scale can be used to assess the response to antipsychotic treatment [7]. Furthermore, PANSS-6 can monitor a patient's achievement of remission, which was defined as a result below 14 points [7].

The functionality of PANSS- 6 in comparison to the PANSS full version was assessed further in two large studies. The first of them analysed the PANSS scale results from the CATIE study (Clinical Antipsychotic Trials of Intervention Effectiveness) [16]. The PANSS and PANSS- 6 results were assessed for their scalability, the correlation of the PANSS- 6 scale results with the full PANSS scale results, the usefulness of the PANSS- 6 scale in remission assessment according to the criteria zostało przesłane do autorów narzędzia w celu sprawdzenia zgodności przekładu $\mathrm{z}$ oryginalną wersją. W kilkukrotnie powtórzonym procesie uwzględniania uwag autorów wywiadu i ponownych ocen uzyskano ostateczną wersję wywiadu. Została ona opracowana graficznie i poddana ocenie praktycznej przez pięciu lekarzy specjalistów psychiatrów, którzy na podstawie badania stanu psychicznego pacjentów z użyciem wywiadu SNAPSI wskazali na konieczność kolejnych drobnych korekt w wykonanej adaptacji. Po ich uzgodnieniu z autorami wywiadu polska adaptacja wywiadu SNAPSI została w $2019 \mathrm{r}$. publicznie udostępniona poprzez stronę internetową http://www.medavante-prophase.com/snapsi/ i może być bezpłatnie używana w działalności leczniczej oraz niekomercyjnych badaniach naukowych.

\section{DYSKUSJA}

SNAPSI i PANSS-6 zostały opracowane w celu umożliwienia ilościowej oceny nasilenia objawów schizofrenii nie tylko w warunkach badań naukowych, lecz także w codziennej pracy klinicznej [8]. Zebranie wywiadu SNAPSI i wykonanie oceny skalą PANSS trwa 15-25 minut. Ocenie podlega sześć podstawowych objawów schizofrenii: trzy objawy pozytywne - urojenia, zachowania omamowe i dezorganizacja pojęciowa, oraz trzy objawy negatywne - bierność/apatia i społeczne wycofanie, spłycenie afektu, brak spontaniczności i płynności rozmowy. Skala PANSS-6 spełnia kryteria skalowalności, tzn. każda jednostka skali ocenia odrębny objaw choroby i wnosi nowe informacje na temat stanu psychicznego pacjenta. Wyniki oceny każdego z tych objawów można zatem sumować, a całkowity wynik skali może być traktowany jako ilościowy pomiar nasilenia choroby - przykładowo dwukrotnie wyższy wynik skali PANSS-6 może być uznawany za dwukrotnie wyższe nasilenie choroby [7]. Warunek skalowalności nie jest spełniony w przypadku pełnej wersji skali PANSS, a także proponowanych wcześniej jej krótszych wersji (PANSS-14 i PANSS-8). Obok długiego czasu potrzebnego na jej wykonanie (40-60 minut) jest poważnym ograniczeniem skali PANSS. Wykonane badania wykazały, że skala PANSS- 6 może być wykorzystywana w celu oceny reakcji na leczenie przeciwpsychotyczne [7] oraz oceny osiągnięcia przez pacjenta remisji, która została zdefiniowana jako wynik poniżej 14 pkt w skali PANSS-6 [7].

Przydatność skali PANSS-6 $\mathrm{w}$ porównaniu z pełną wersją skali PANSS została dodatkowo oceniona $\mathrm{w}$ dwóch kolejnych ważnych badaniach. W pierwszym z nich wykonano analizę wyników skali PANSS z badania CATIE (Clinical Antipsychotic Trials of Intervention Effectiveness) [16]. Ocenie ponownie poddano skalowalność obu skal - skali PANSS i PANSS-6, korelację wyników skali PANSS-6 z wynikami pełnej skali PANSS, użyteczność skali PANSS-6 w ocenie remisji zgodnie 
proposed by Andreasen et al. [17], and the usefulness of the PANSS- 6 scale in measuring the efficacy of 5 drugs evaluated in the CATIE study. It was found again that the PANSS- 6 scale meets the scalability criteria - the condition which is not met in the case of PANSS full version. The results of the PANSS- 6 scale strongly correlate with the full PANSS-30 scale results, the Spearman correlation coefficient being 0.86 . The PANSS- 6 scale identifies people meeting the remission criteria with a diagnostic accuracy of 0.99 . The $95 \%$ confidence interval was found to be very narrow $(0.99-0.99)$. This can be described as a powerful result which clearly indicates the possible use of PANSS-6 to monitor the patient's achievement of remission. The differences in the efficacy of antipsychotic drugs found in the CATIE study based on PANSS scores were also demonstrated in the PANSS-6 score [16]. Additionally, the differences in the efficacy of antipsychotic drugs found in the CATIE study was similar in both PANSS and PANSS-6 [16].

The functionality of PANSS- 6 scale was further assessed in chronically ill, drug-resistant patients, again using CATIE data obtained from patients qualified for clozapine treatment (study arm 2E) [18]. This time the analysis included the scalability of the PANSS- 6 scale, its correlation with the assessment of the full PANSS scale, and the usefulness of the PANSS-6 scale in determining remission status and assessing the efficacy of clozapine treatment compared to other antipsychotic treatment. The study confirmed the scalability of PANSS- 6 and the lack thereof in the full version of the scale. The correlation of PANSS- 6 results with the PANSS scale results was 0.85 in the Spearman rank correlation test. The PANSS- 6 result of below 14 points indicated that the patient met the criteria for remission [17] with 100\% sensitivity and $99 \%$ specificity. Positive predictive value was $88 \%$ and negative $100 \%$. The total diagnostic accuracy of the PANSS-6 scale for remission was 99\% (95\% confidence interval 96-99\%). Assessments with both: the PANSS- 6 scale and PANSS full version showed that in the case of drug-resistant patients (CATIE study arm 2E), only clozapine treatment reduced the severity of symptoms in the first three months of treatment. No treatment was found to be effective for any of the evaluated drugs (clozapine, quetiapine, olanzapine, risperidone) in the following months (from 3 to 6 months).

The study assessing congruence of PANSS scores among people with diverse clinical experience in the treatment of patients with schizophrenia (two psychiatrists, three residents of the first year of specialization, a clinical psychologist and a research psychologist) found the assessment scores to be highly consistent. The determined inter-class correlation coefficient (ICC) was 0.74 (ICC values $>0.75$ are considered as excellent, values from 0.40 to 0.74 as moderate to good, values $<0.40$ as poor compliance). For individual items of the PANSS-6 scale, the ICC coeffi- z kryteriami zaproponowanymi przez Andreasen i wsp. [17], użyteczność skali PANSS-6 w pomiarze skuteczności pięciu ocenianych w badaniu CATIE leków. Ponownie stwierdzono, że skala PANSS-6 spełnia kryteria skalowalności, warunek ten nie jest spełniony w przypadku pełnej wersji skali PANSS. Wyniki ocen skalą PANSS-6 są silnie skorelowane z wynikami pełnej skali PANSS-30 stwierdzony współczynnik korelacji Spearmana wynosił 0,86 . Skala PANSS-6 identyfikuje osoby spełniające kryteria remisji z dokładnością diagnostyczną na poziomie 0,99 , a stwierdzony $95 \%$ przedział zaufania był bardzo wąski $(0,99-0,99)$. Jest to zatem silny wynik, jednoznacznie wskazujący na możliwość stosowania skali PANSS-6 $\mathrm{w}$ celu oceny osiągnięcia stanu remisji przez pacjenta. Różnice w skuteczności leków przeciwpsychotycznych stwierdzone w badaniu CATIE na podstawie ocen skalą PANSS wykazano również $\mathrm{w}$ ocenie na podstawie skali PANSS-6 [16].

Ocena użyteczności skali PANSS-6 została też wykonana u przewlekle chorych, lekoopornych pacjentów, ponownie $\mathrm{z}$ wykorzystaniem danych $\mathrm{z}$ badania CATIE uzyskanych od chorych zakwalifikowanych do leczenia klozapiną (ramię 2E badania) [18]. Analiza obejmowała ponownie skalowalność narzędzia PANSS-6, jej korelację z oceną pełną skalą PANSS, użyteczność skali PANSS-6 $\mathrm{w}$ stwierdzaniu stanu remisji i ocenie skuteczności leczenia klozapiną $\mathrm{w}$ porównaniu $\mathrm{z}$ innym leczeniem przeciwpsychotycznym. W badaniu potwierdzono skalowalność PANSS-6 i jej brak dla pełnej wersji skali. Korelacja wyników PANSS-6 z wynikami pełnej wersji skali PANSS wynosiła $0,85 \mathrm{w}$ teście korelacji rangowej Spearmana. Wynik w skali PANSS-6 poniżej 14 pkt wskazywał pacjentów spełniających kryteria remisji [17] z 100-procentową czułością, 99-procentową swoistością. Dodatnia wartość predykcyjna wynosiła $88 \%$, a ujemna $100 \%$. Całkowita dokładność diagnostyczna skali PANSS-6 dla stwierdzania stanu remisji wyniosła 99\% (95\% CI: 96-99\%). Oceny skalą PANSS-6, podobnie jak oceny pełną wersją skali PANSS, wykazały, że w przypadku lekoopornych pacjentów (ramię 2E badania CATIE) tylko leczenie klozapiną zmniejszało nasilenie objawów choroby podczas pierwszych trzech miesięcy leczenia. W kolejnych miesiącach leczenia (od trzech do sześciu miesięcy) takiego efektu nie stwierdzono dla żadnego z ocenianych leków (klozapina, kwetiapina, olanzapina, risperidon).

W badaniu analizującym zgodność ocen skalą PANSS między osobami ze zróżnicowanym doświadczeniem klinicznym w leczeniu chorych na schizofrenię (siedem osób: dwóch lekarzy psychiatrów, trzech rezydentów pierwszego roku specjalizacji, psycholog kliniczny i psycholog zajmujący się badaniami naukowymi) stwierdzono wysoką zgodność ocen. Wyznaczony współczynnik korelacji wewnątrzklasowej (ICC) wyniósł 0,74 (wartości ICC $>0,75$ traktowane są jako doskonała zgodność, $0,40-0,74$ jako zgodność od umiarkowanej do dobrej, < 0,40 jako 
cients were: delusions 0.68 , hallucinatory behaviours 0.76 , conceptual disorganization 0.47 , passivity/apathy and social withdrawal 0.69 , blunt affect 0.52 , lack of spontaneity and fluent conversation 0.45 . The median of differences in the PANSS-6 scores between six evaluators without a completed training in PANSS assessment and a person holding a certificate confirming proficiency in performing the PANSS scale was $12.7 \%$ [13]. The above results indicate the practicality of using the PANSS- 6 scale also in terms of the assessment's congruent outcomes among various doctors and psychologists.

In the study performed by another scientific group, it was investigated whether the early change in the PANSS, PANSS- 8 and PANSS- 6 scores is a sensitive and reliable marker for a patient's improvement (remission) being a consequence of antipsychotic treatment [19]. The results of the PANSS scale from 3 studies involving 270 patients with schizophrenia were analysed. It was found that both abbreviated versions - PANSS-8 (additionally evaluating mannerisms - G5 and abnormal thinking content - G9) and PANSS-6 are internally consistent and scalable. Furthermore, their results are highly correlated with the results of the PANSS full version. Therefore, they indicate patients who achieve improvement and remission as a result of treatment with good sensitivity [19].

The research results described indicate that the quantitative measurement of the severity of schizophrenia symptoms can be performed in daily clinical practice, and is not only limited to scientific research. Short versions of the PANSS scale, e.g. the PANSS- 6 scale, allow for a quantitative, scalable measurement of the severity of illness. They have a high degree of congruence with the assessment results obtained using the full version of the PANSS scale. What is more, they are sensitive to changes in symptoms during antipsychotic treatment and identify patients who achieved remission because of it. Additionally, they are characterized by high degree of congruence when it comes to the evaluations carried out by different raters, and the assessments are correct and consistent even when they are carried out by people with no clinical experience, such as medical students [20]. The results obtained with the use of the SNAPSI interview and the full structured interview for the PANSS scale (SCI-PANSS) are also consistent [21]. Nevertheless, these promising results must be verified in large prospective clinical trials. In future it may be necessary to develop transformation tables, which will enable the conversion of results between PANSS versions [6].

In addition, for the Polish language version of SNAPSI it is also necessary to collect data enabling the analysis of the accuracy of the assessments made using the PANSS- 6 scale in comparison to the PANSS scale, as well as the reliability of these assessments, by checking whether the assessments made by clinicians with varying degrees of experience are similar. These analyses, apart słaba zgodność wyników). Dla poszczególnych jednostek skali PANSS-6 współczynniki ICC wynosiły: urojenia 0,68 , zachowania omamowe 0,76 , dezorganizacja pojęciowa 0,47 , bierność/apatia i społeczne wycofanie 0,69 , spłycenie afektu 0,52 , brak spontaniczności i płynności rozmowy 0,45. Mediana różnic w ocenach skalą PANSS-6 pomiędzy osobą posiadającą certyfikat potwierdzający biegłość w wykonywaniu skali PANSS a sześcioma osobami, które nie ukończyły takiego szkolenia, wynosiła $12,7 \%$ [13]. Te wyniki wskazują na praktyczność stosowania skali PANSS-6 również w aspekcie zgodności ocen pomiędzy różnymi lekarzami i psychologami.

W badaniu przeprowadzonym przez inną grupę naukowców oceniono, czy wczesna zmiana wyniku skal PANSS, PANSS-8 i PANSS- 6 jest czułym i wiarygodnym markerem osiągnięcia przez pacjenta stanu poprawy lub remisji w wyniku zastosowanego leczenia przeciwpsychotycznego [19]. Analizie poddano wyniki ocen skalą PANSS z trzech badań z udziałem 270 chorych na schizofrenię. Stwierdzono, że obie skrócone wersje - PANSS-8 (dodatkowo oceniająca manieryzmy - G5, oraz niezwykłe treści myślenia - G9) i PANSS-6 - są spójne wewnętrznie, skalowalne, ich wynik jest wysoce skorelowany $\mathrm{z}$ wynikami pełnej wersji skali PANSS oraz z wysoką czułością wskazują pacjentów, którzy uzyskują poprawę i remisję w wyniku zastosowanego leczenia [19].

Przedstawione wyniki badań pokazują, że ilościowy pomiar nasilenia objawów schizofrenii może być wykonywany także $\mathrm{w}$ warunkach codziennej praktyki klinicznej, a nie tylko badań naukowych. Krótkie wersje skali PANSS, np. skala PANSS-6, umożliwiają ilościowy, skalowalny pomiar nasilenia objawów choroby, o dużej zgodności z wynikami oceny pełną wersją skali PANSS. Są czułe na zmianę objawów w trakcie stosowanego leczenia przeciwpsychotycznego i wskazują pacjentów, którzy w wyniku jego zastosowania osiągają poprawę i remisję. Cechuje je także duża zgodność ocen wykonywanych przez różne osoby, a oceny te są poprawne i zgodne, nawet gdy przeprowadzają je osoby bez doświadczenia klinicznego, takie jak studenci medycyny [20]. Zgodne są także wyniki uzyskiwane z użyciem wywiadu SNAPSI i pełnego strukturyzowanego wywiadu do skali PANSS (SCI-PANSS) [21]. Te obiecujące wyniki muszą być jednak zweryfikowane w prospektywnych dużych badaniach klinicznych, konieczne jest też wyznaczenie tablic przeliczeniowych umożliwiających konwersję wyników krótkich skal PANSS na wynik pełnej skali [6].

Ponadto w odniesieniu do polskiej wersji językowej SNAPSI wskazane jest zebranie danych umożliwiających analizę trafności ocen wykonanych $\mathrm{z}$ użyciem skali PANSS-6 $\mathrm{w}$ porównaniu ze skalą PANSS oraz analizę rzetelności tych ocen poprzez sprawdzenie, czy oceny wykonane przez osoby o różnym stopniu doświadczenia klinicznego są podobne. Analizy te, obok ich odniesie- 
from their reference to the results of the original methods, should also include an assessment of whether the time gain resulting from the use of PANSS- 6 instead of PANSS is as significant as it is for English-language tools.

However, the real measure of the practicality and usefulness of short PANSS scales will be whether psychiatrists freely implement them in their daily clinical practice - whether they use them as routinely as an internist doctor uses blood pressure measurement. Eager mental health professionals can make such an attempt now. The Polish adaptation of the SNAPSI interview is available to them, among other language versions, on the website: http://www.medavante-prophase.com/snapsi/. It can be used free of charge in medical and non-commercial scientific research. nia do wyników oryginalnych metod, powinny także ocenić, czy zysk czasowy wynikający z użycia PANSS-6 wobec PANSS jest tak samo znaczący jak dla narzędzi anglojęzycznych. Prawdziwą miarą użyteczności wywiadu SNAPSI i skali PANSS-6 będzie jednak to, czy lekarze psychiatrzy wdrożą je do swojej codziennej praktyki klinicznej i będą z nich korzystali w równym stopniu jak np. lekarz internista, który korzysta z pomiarów ciśnienia krwi i innych parametrów fizjologicznych. Chętni lekarze psychiatrzy mogą podjąć taką próbę już teraz. Polska adaptacja wywiadu SNAPSI jest dla nich dostępna wśród innych wersji językowych na stronie internetowej http://www.medavante-prophase.com/snapsi/ i może być używana bezpłatnie w działalności leczniczej i niekomercyjnych badaniach naukowych.

\section{Conflict of interest / Konflikt interesu}

Absent. / Nie występuje.

Financial support / Finansowanie

Absent. / Nie występuje.

\section{References / Piśmiennicłwo}

1. Jarema M. Leczenie farmakologiczne schizofrenii. Standardy leczenia farmakologicznego niektórych zaburzeń psychicznych. Wydanie 2. Gdańsk: Via Medica; 2015, p. 1-54.

2. Kay SR, Fiszbein A, Opler LA. The positive and negative syndrome scale (PANSS) for schizophrenia. Schizophr Bull 1987; 13: 261-276.

3. Leucht S, Kane JM, Kissling W, Hamann J, Etschel E, Engel RR. What does the PANSS mean? Schizophr Res 2005; 79: 231-238.

4. Szulc A, Dudek D, Samochowiec J, Wojnar M, Heitzman J, Gałecki P. Recommendations for the treatment of schizophrenia with negative symptoms. Standards of pharmacotherapy by the Polish Psychiatric Association (Polskie Towarzystwo Psychiatryczne), part 2. Psychiatr Pol 2019; 53: 525-540.

5. Szulc A, Samochowiec J, Gałecki P, Wojnar M, Heitzman J, Dudek D. Recommendations for the treatment of schizophrenia with negative symptoms. Standards of pharmacotherapy by the Polish Psychiatric Association (Polskie Towarzystwo Psychiatryczne), part 1. Psychiatr Pol 2019; 53: 497-524.

6. Lindenmayer JP. Are shorter versions of the positive and negative syndrome scale (Panss) doable? A critical review. Innov Clin Neurosci 2017; 14: 73-76.

7. Østergaard SD, Lemming OM, Mors O, Correll CU, Bech P. PANSS-6: a brief rating scale for the measurement of severity in schizophrenia. Acta Psychiatr Scand 2016; 133: 436-444.

8. Østergaard SD, Opler MGA, Correll CU. Bridging the measurement gap between research and clinical care in schizophrenia: positive and negative syndrome scale-6 (PANSS-6) and othassessments based on the simplified negative and positive symptoms interview (SNAPSI). Innov Clin Neurosci 2017; 14: 11-12.

9. Overall JE, Gorham DR. The Brief Psychiatric Rating Scale. Psychol Rep 1962; 10: 799-812.

10. Wójciak P, Górna K, Domowicz K, Jaracz K, Gołębiewska K, Michalak M, et al. Polish version of the Brief Negative Symptom Scale (BNSS). Psychiatr Pol 2019; 53: 541-549.

11. Kirkpatrick B, Strauss GP, Nguyen L, Fischer BA, Daniel DG, Cienfuegos A, et al. The brief negative symptom scale: psychometric properties. Schizophr Bull 2011; 37: 300-305.

12. Guy W. The Clinical Global Impression Scale. ECDEU Assessment Manual for Psychopharmacology-Revised. Rockville, MD: US Dept. of Health, Education \& Welfare, ADAMHA, NIMH Psychopharmacology Research Branch; 1976, p. 218-222.

13. Kølbæk P, Blicher AB, Buus CW, Feller SG, Holm T, Dines D, et al. Inter-rater reliability of ratings on the sixitem Positive and Negative Syndrome Scale (PANSS-6) obtained using the Simplified Negative and Positive Symptoms Interview (SNAPSI). Nord J Psychiatry 2018; 72: 431-436.

14. Vijver FVD, Hambleton RK. Translating tests. European Psychologist 1996; 1: 89-99. 
15. Hornowska E. Standardy dla testów stosowanych w psychologii i pedagogice. Gdańsk: GWP; 2007.

16. Østergaard SD, Foldager L, Mors O, Bech P, Correll CU. The validity and sensitivity of PANSS-6 in the clinical antipsychotic trials of intervention effectiveness (CATIE) study. Schizophr Bull 2018; 44: 453-462.

17. Andreasen NC, Carpenter WT, Kane JM, Lasser RA, Marder SR, Weinberger DR. Remission in schizophrenia: proposed criteria and rationale for consensus. Am J Psychiatry 2005; 162: 441-449.

18. Østergaard SD, Foldager L, Mors O, Bech P, Correll CU. The validity and sensitivity of PANSS-6 in treatmentresistant schizophrenia. Acta Psychiatr Scand 2018; 138: 420-431.

19. Lin CH, Lin HS, Lin SC, Kuo CC, Wang FC, Huang YH. Early improvement in PANSS-30, PANSS-8, and PANSS-6 scores predicts ultimate response and remission during acute treatment of schizophrenia. Acta Psychiatr Scand 2018; 137: 98-108.

20. Hansen J, Dines D, Opler M, Mors O, Østergaard SD, Kølbæk P. Reliability of core schizophrenia symptoms ratings using the six-item positive and negative syndrome scale (PANSS-6) performed by medical students. Schizophr Bull 2020; 46 (Suppl 1): S131-S132.

21. Kølbæk P, Dines D, Holm T, Blicher AB, Sørensen RD, O’Leary KM, et al. Clinical validation of the six-item Positive and Negative Syndrome Scale (PANSS-6). Schizophr Bull 2020; 46 (Suppl 1): S147-148. 